\title{
教育講演
}

\section{5. 悪性リンパ腫の治療}

\section{飛内 賢正}

Key words : malignant lymphoma, Hodgkin lymphoma, non-Hodgkin lymphoma, rituximab

\section{1. 疫学および病因}

1996 年のわが国における悪性リンパ腫の粗罹 患率は人口 10 万当たり男 10.0 , 女 7.2 である.

感染性因子としては, EB（Epstein-Barr）ウ イルス, ヒトT細胞白血病ウイルスI型（human T-cell leukemia virus type-I ; HTLV-I)，ヒトへ ルペスウイルス 8 型, ヘリコバクター・ピロリ などが，化学的および物理的因子としては化学 療法, 放射線治療などが挙げられる. 免疫不全 状態におけるリンパ腫発生の増加が知られてい る. Sjögren症候群，慢性甲状腺炎などの自己 免疫疾患の局所に粘膜関連リンパ組織リン パ腫 (mucosa-associated lymphoid tissue lymphoma；MALT lymphoma)が高頻度に発生す る.

\section{2. 病理組織分類}

悪性リンパ腫の病理組織分類は, 発生母地と なる免疫系の多様な細胞構成を反映して, 悪性 腫瘍の病理組織分類の中でも最も複雑な分類で ある。

1997 年に発表されたWHO (World Health Organization）分類 ${ }^{1)}$ はリンパ系腫瘍（悪性リンパ

とびない けんせい：国立がんセンター中央病院第一 領域外来部
腫とリンパ性白血病，形質細胞腫瘍の総称）だ けではなく骨髄性白血病を含めた造血器腫瘍全 体を包含する分類である. WHO分類では, リン パ系腫瘍を Hodgkinリンパ腫（Hodgkin lymphoma：HL）と非 Hodgkinリンパ腫（nonHodgkin lymphoma；NHL)に大別し, 更に前駆 型（未分化型）と成熟型（分化型，末梢性）に 分け，それぞれをB細胞系列， T細胞系列 $(\mathrm{NK}$ 細胞系列を含む）に分ける. WHO分類でlist up されているリンパ系腫瘍の疾患単位は 30 以上に 及び, 各疾患単位の発生頻度には地域差と人種 差が存在する。欧米白人に比し，日本人では， 滤胞性リンパ腫, B細胞性小細胞型リンパ腫 (Bsmall lymphocytic lymphoma ; B-SLL), Hodgkinリンパ腫, 皮膚T細胞リンパ腫（cutaneous T-cell lymphoma；CTCL）の発生頻度が低く, 成人 T細胞白血病リンパ腫 (adult T-cell leukemialymphoma ; ATL), NK (natural killer) 細胞リ ンパ腫, 膿胸関連リンパ腫の発生頻度が高い.

欧米白人を主な対象とする，1,403 例のNHL の検討によると, 頻度の高い疾患単位は, びま ん性大細胞型B細胞リンパ腫 (diffuse large B-cell lymphoma；DLBCL) (31\%), 滤胞性リンパ腫 (22\%), MALTリンパ腫 (8\%), B-CLL(B-chronic lymphocytic leukemia)/B-SLL (7\%), マントル 細胞リンパ腫 $(6 \%)$ ，末梢T細胞リンパ腫 $(4 \%)$ である ${ }^{2)}$. 同様の検討が日本人リンパ腫患者 3,194 例を対象に行われた ${ }^{3)}$. HLは 4\%で, B細胞リン 
パ腫が $69 \%, \mathrm{~T} / \mathrm{NK}$ 細胞リンパ腫が $25 \%$ を占め た. NHLの中で高頻度であった疾患単位は, DLBCL (35\%), MALTリンパ腫 (9\%), ATL (8\%), 濾胞性リンパ腫 $(7 \%)$ ，末梢T細胞リン パ腫 $(7 \%)$, マントル細胞リンパ腫 $(3 \%)$, 鼻 $\mathrm{NK} / \mathrm{T}$ 細胞リンパ腫（3\%）であった.

\section{3. 染色体異常とがん遺伝子}

B細胞腫瘍に認められる多くの染色体転座に関 わっているのが免疫グロブリン $(\mathrm{Ig})$ 重鎖 $(\mathrm{IgH})$ の遺伝子座である 14q32 であり, 免疫グロブリ ン軽鎖 $\mathrm{K}$ 鎖の $2 \mathrm{p} 11$ と入鎖の $22 \mathrm{q} 11$ もしばしば染色 体転座に関わる，転座相手の染色体転座部位に 滤胞性リンパ腫におけるbcl-2（18q21），マント ル細胞リンパ腫におけるbcl-1（11q13）などのが ん関連遺伝子が存在し, がん関連遺伝子の脱制 御と過剩発現が認められる. bcl-2 の遺伝子産物 はアポトーシスを抑制し, $b c l-1$ の遺伝子産物 （cyclin D1）は細胞回転に関与する。また，B 細胞リンパ腫の一部に, 染色体 3q27 に位置する $b c l-6$ 遺伝子の再構成と発現高進が認められる. また，MALTリンパ腫で認められるt $(11 ； 18)$ ではAPI2-MALT1 遺伝子再構成が起こっている が,アポトーシス制御に関連した遺伝子であり, 細胞死の抑制がリンパ腫発症の第一段階として 重要な役割を果たしている.

がん抑制遺伝子の研究も進められており, p53 遺伝子変異がATLや濾胞性リンパ腫のdisease progressionに関与することが報告された。 DLBCLが遺伝子発現様式から肧中心B細胞型と 活性化B細胞型に大別され, 予後が異なることが 判明した ${ }^{4)}$.

\section{4. 診断}

\section{1) 質的診断}

HLがリンパ節病変を主体とするのに対し, NHL はリンパ節だけでなく全身諸蔵器にも発生する.
発生臓器には, 皮膚, 脳, 眼, 鼻腔, 副鼻腔, 唾液腺, 甲状腺, 乳腺, 肺, 縦隔, 胸膜, 消化 管, 肝, 脾, 精巣, 卵巣, 骨などがあり, NHL は全ての蔵器に発生すると言ってもよい. 節外 性リンパ腫の細胞起源, 悪性度, 臨床病態には, 発生臓器による一定の特徵がある.

悪性リンパ腫の病理組織診断の精度向上を図 るには，抗体を用いた免疫組織学的検索もしく はフローサイトメトリー法による腫瘍細胞の免 疫学的表現型検索が有用である.T細胞抗原の中 ではCD3 の特異性が高い. B細胞系列の指標にな るのは, 表面免疫グロブリン (S-Ig), CD19, CD20, CD79aなどであるが, CD20 が最も広く用いられ ている. NK細胞の形質としてはCD56 が用いら れている. 未梢 T細胞リンパ腫を診断する場合は, 血清抗HTLV-I抗体を検索してATLの可能性を検 討する必要がある.

\section{2）病変の広がりの検索（病期診断）}

理学所見に加えて, 胸部X線, 頸〜鼠径部CT (computed tomography), 上部消化管検査，骨 髄穿刺/生検などにより病変の広がりを検索する. 近年, positron emission tomography (PET) 検 查の病期診断および治療効果判定における有用 性が注目されている. 病期分類は, NHLではAnn Arbor分類が，HLではその修正版である Cotswolds分類 ${ }^{5}$ が用いられる.

\section{5. 治療}

\section{1) $\mathrm{HL}$}

放射線療法と化学療法が有効で, 病期診断に 基づく適切な治療により高率の長期生存が期待 できる，図 1 にHLの治療アルゴリズムを示す.

（1）早期Hodgkinリンパ腫（IA期，IIA期，巨 大腫瘤なし, B症状なし)

かつては広範囲放射線照射が標準治療とされ たが，化学療法と照射野を縮小した放射線治療 併用, もしくは化学療法単独の良好な成績が報 告されている。一方, 長期生存例増加に伴い, 


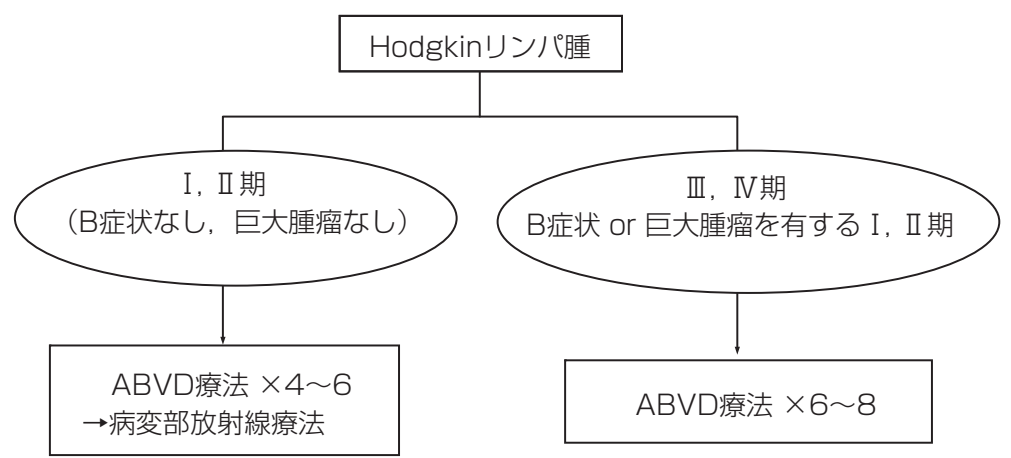

図 1. Hodgkin リンパ腫の治療アルゴリズム

白血病, 乳がん, 肺がんなどの二次性悪性腫瘍 や, 生殖器, 心, 肺などの臓器障害が問題になっ ており，晚期毒性デー夕に基づいて適切な初回 治療が再検討されている.

進行期におけるABVD療法 (doxorubicin, bleomycin, vinblastine, dacarbazine)の標準的化学 療法としての確立 ${ }^{6}$ に基づき，ABVD療法 4〜6 コース施行後の局所放射線照射が標準治療と考 えられている7).

（2）進行期（III，IV期，B症状や巨大腫瘤を有 する।， I期）

MOPP療法 (nitrogen mustard, vincristine, procarbazine, prednisone), ABVD療法, MOPP/ ABVD交代療法などが代表的な化学療法レジメ ンである，MOPP療法はわが国では， nitrogen mustardの代りにcyclophosphamideを用いたCMOPP療法で代用されることが多い. 進行期患者 に対するMOPP療法, ABVD療法, MOPP/ABVD 交替療法の 3 群比較試験の結果, 標準的化学療 法はABVD療法である ${ }^{6)}$.

\section{2）中高悪性度NHL}

（1）限局期（I期および連続的II期）

化学療法と局所放射線療法の併用が行われる. その場合の化学療法はCHOP療法 (cyclophosphamide, doxorubicin, vincristine, prednisone) が推奨され, 約 $80 \%$ 者に長期無病生存が期待で きる. I, II期の中高悪性度リンパ腫症例に対し
て, CHOP 8 コース群とCHOP 3 コース後にIFRT (involved field radiation therapy) 施行群を 比較した第III相試験の結果が報告され，後者の 併用療法群の治療成績が上回った ${ }^{8)}$. 限局期中高 悪性度リンパ腫は病理組織学的に大半がDLBCL のため, 限局期DLBCLにおいては, キメラ型抗 CD20 抗体リッキシマブとCHOP療法を併用した R-CHOP療法 3 コース後の局所放射線療法が現在 の標準治療と考えられている.

(2) 進行期

$\mathrm{II} \sim \mathrm{IV}$ 期の進行期患者は, CHOP療法などの標 準的化学療法により半数近くが治癒可能である ${ }^{9)}$. doxorubicinを含む併用化学療法を施行された 3,000 例以上の中高悪性度リンパ腫における予後 因子解析結果が報告された ${ }^{10)}$. 年歯令, 臨床病期, 節外病変数, performance status (PS), LDH (lactate dehydrogenase)の 5 つが有意な予後因 子であり，これらの組み合せによる国際予後因 子指標 (international prognostic index ; IPI) が 報告された. IPIは, 個々の患者の治療選択指針 のみならず, 臨床試験の対象患者設定やランダ ム化試験における割付調整因子としても有用で ある。

未治療高歯DLBCL患者を対象としたR-CHOP 療法とCHOP療法の第III相試験の結果が報告さ れ, R-CHOP群のevent-free survival (EFS) と overall survivalはCHOP群より有意に延長して 


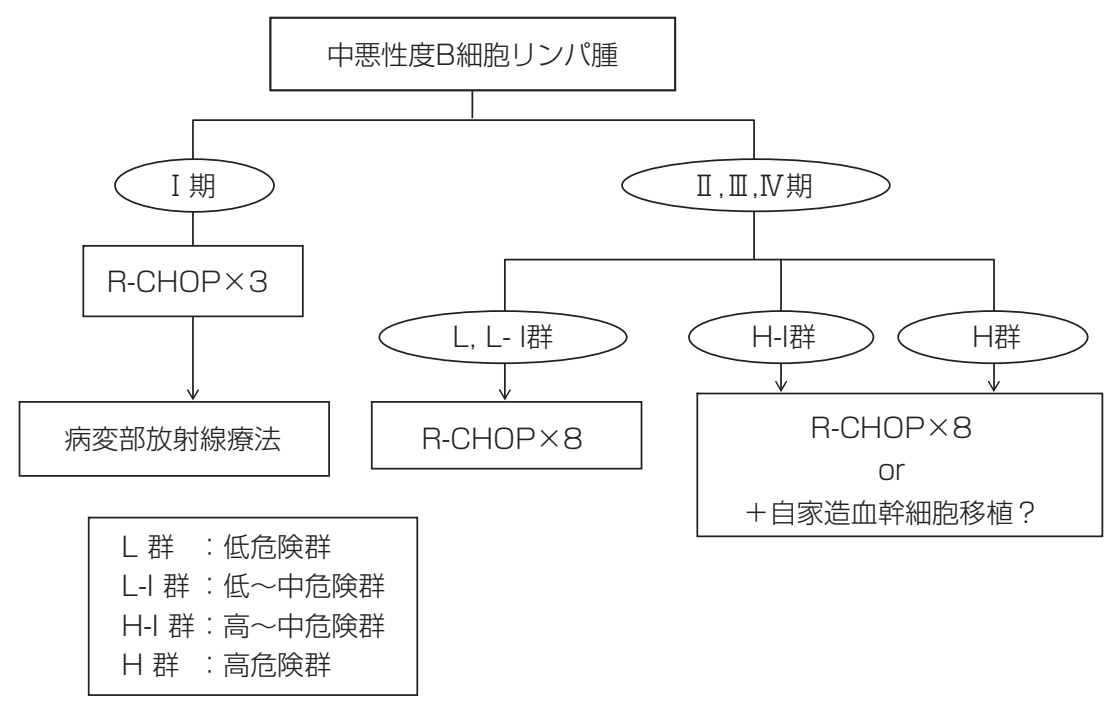

図 2. 中悪性度 B 細胞リンパ腫の治療アルゴリズム

いた ${ }^{11)}$. R-CHOP療法のCHOP療法に対する優位 性は, 米国のIntergroup study, 欧州のMInT (Mab-Thera International Trial) studyでも確認 され, 進行期DLBCLの標準治療はR-CHOP療法 である。

図 2 に中悪性度B細胞リンパ腫の治療アルゴリ ズムを示す。

3）低悪性度B細胞リンパ腫

I, II期では局所放射線療法が一般的な治療選 択であり，約 $50 \%$ に 10 年無病生存が期待でき る.

III, IV期では無治療経過観察 (watchful wait), アルキル化薬単剂, doxorubicinを含まない併用 化学療法, doxorubicinを含む併用化学療法, 自 家造血幹細胞移植（autologous hematopoietic stem cell transplantation; AHSCT) 併用大量化 学療法などの多種類の治療が行われてきたが, 標準的治療が確立されておらず, 組織学的進展 などによって大半の患者が最終的に死に至るこ とが問題である.

キメラ型抗CD20 抗体リツキシマブは再発・再 燃低悪性度B細胞リンパ腫に対して 50〜 60\%の 奏効割合が得られ ${ }^{12}$, CHOP療法, フルダラビン
などとの併用の優れた成績が報じられた，放射 性同位元素（RI）標識抗体も検討されており, 中でも RI標識抗CD20 抗体の研究が活発に進めら れている. 図 3 に低悪性度B細胞リンパ腫の治療 アルゴリズムを示す.

\section{4）下細胞性リンパ芽球性リンパ腫}

若年男性に多く, 縦隔腫瘤を伴い, 骨䯣や中 枢神経に浸潤しやすい高悪性度リンパ腫で，TALL (T-acute lymphocytic leukemia) と一連の 疾患である. 成人ALLと同様に, 中枢神経浸潤 予防を含む多剂併用による強力な治療レジメン が選択される。

\section{5）Burkittリンパ腫}

急速に増大し，骨髄浸潤や中枢神経浸潤をき たしやすい高悪性度B細胞リンパ腫で, B-ALL と一連の疾患である. CODOX-M/IVAC (cyclophosphamide, vincristine, doxorubicin, methotrexate/ifosfamide, etoposide, cytarabine, methotrexate）療法 ${ }^{13)}$ などの小児レジメンを成人例に 適用することによる治療成績改善が報告されて いる.

6）成人T細胞白血病リンパ腫（ATL）

治療選択には病型診断が重要であり, 化学療 


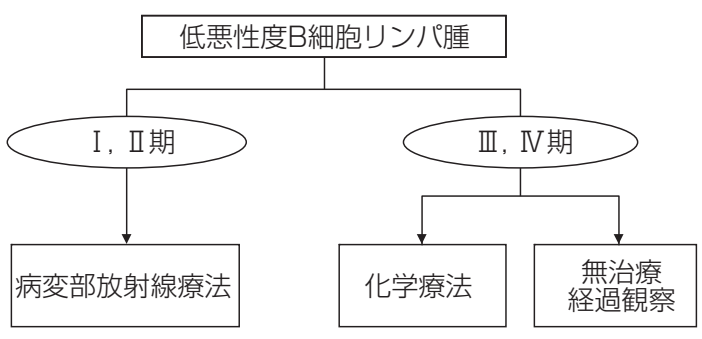

図 3. 低悪性度 B 細胞リンパ腫の治療アルゴリズム

法の対象になるのは急性型とリンパ腫型であ $る^{14)}$. 第 2 世代の多剂併用療法やdeoxycoformycinを含む併用化学療法の第II相試験が施行され たが，治療成績の改善が得られなかった，次い で, carboplatin, MCNUなどの非交差耐性薬剤 を組み込み, G-CSF (granulocyte-colony stimulating factor）を併用して用量強度増強を図った 8 凨による化学療法(LSG15)の第II相試験 (JCOG (Japan Clinical Oncology Group Study) 9303) が 施行され，奏効割合 $81 \%$, 完全奏効割合 $35 \%$, 2 年生存率 $31 \%$ と, JCOG臨床試験中, 最善の成 績が得られた ${ }^{15)}$. 本レジメンの有効性確認を目的 として, 2 週毎のbiweekly CHOP療法との第III 相試験 (JCOG9801) が実施され, LSG15 レジメ ンの優位性が確認された ${ }^{16)}$.

\section{7) NHLの救援化学療法}

中高悪性度リンパ腫（大半がDLBCL）の約半 数と低悪性度B細胞リンパ腫の大半は再発・再燃 し, 救援化学療法の対象となり, DHAP（dexamethasone, cytarabine, cisplatin) 療法, ESHAP (etoposide, methylprednisolone, cytarabine, cisplatin) 療法, EPOCH (etoposide, prednisone, vincristine, cyclophosphamide, doxorubicin）療 法, ICE (ifosfamide, carboplatin, etoposide) 療 法などがよく用いられている。これらは, 非交 差耐性の抗がん薬である cisplatin, cytosine arabinosideや, etoposide, 大量のステロイドを含ん だもの（DHAP療法, ESHAP療法)や, vincristine, doxorubicinの投与方法を持続点滴に変える ことにより薬剤耐性打破をねらったもの $(\mathrm{EPOCH}$

\section{表 ．悪性リンパ腫診療における内科医の行動目標}

1. 悪性リンパ腫の基本的事項の認識

1) ほぼ全ての臓器に発生する多様な腫瘍

2）血液病理医による正確な病理診断が必須

3）複数の診療科によるチーム医療が必要

4）複数の有効な治療手段, 疾患によっては経過観察も

2. 血液內科専門医への迅速な紹介

3. 合併症への支持療法（発熱時の抗生物質投与など）

4. 緩和ケア

療法)で, B細胞リンパ腫ではリツキシマブが併 用される。

8）自家造血幹細胞移植（AHSCT）併用大量 化学療法 (high-dose chemotherapy; HDC)

初回化学療法による完全奏効到達後の再発後 にDHAP療法が奏効した中高悪性度リンパ腫患者 を対象として, HDC群とDHAP療法継続群の第 III相試験の結果が報告され, overall survival EFSにおいてHDC群が勝った ${ }^{17)}$.

\section{6. 悪性リンパ腫診療における内科医の役 割}

血液内科医，腫瘍内科医など，リンパ腫専門 医以外の内科医にとって，悪性リンパ腫の基本 的事項の認識が重要であり, 専門医への迅速な 紹介に加えて, 合併症併発時の支持療法をお願 いしたい，表に，悪性リンパ腫患者の診療にお ける内科医の行動目標を示す。

\section{文献}

1) Harris NL, et al:World Health Organization classification of neoplastic diseases of the hematopoietic and lymphoid tissues: report of the Clinical Advisory Committee Meeting-Airlie House, Virginia, November 1997. J Clin Oncol 17 : 3835-3849, 1999.

2) The Non-Hodgkin's Lymphoma Classification Project: A clinical evaluation of the International Lymphoma Study Group classification of non-Hodgkin's lymphoma. Blood 89 : 3909-3918, 1997.

3) Lymphoma Study Group of Japanese Pathologists: The World Health Organization classification of malignant lymphomas in Japan : incidence of recently recognized 
entities. Pathol Int $50:$ 696-702, 2000.

4) Alizadeh AA, et al : Distinct types of diffuse large B-cell lymphoma identified by gene expression profiling. Nature $403:$ 503-511, 2000.

5) Lister TA, et al : Report of a committee convened to discuss the evaluation and staging of patients with Hodgkin's disease:Cotswolds meeting. J Clin Oncol 7:1630-1636, 1989.

6) Canellos GP, et al: Chemotherapy of advanced Hodgkin's disease with MOPP, ABVD, or MOPP alternating with ABVD. N Engl J Med 327 : 1478-1484, 1992.

7) Bonadonna $G$, et al : ABVD plus subtotal nodal versus involved-field radiotherapy in early-stage Hodgkin's disease : long-term results. J Clin Oncol 22 : 2835-2841, 2004.

8) Miller TP, et al:Chemotherapy alone compared with chemotherapy plus radiotherapy for localized intermediateand high-grade non-Hodgkin's lymphoma. N Engl J Med 339 : 21-26, 1998.

9) Fisher RI, et al : Comparison of a standard regimen (CHOP) with three intensive chemotherapy regimens for advanced non-Hodgkin's lymphoma. N Engl J Med 328 : 1002-1006, 1993.

10) A predictive model for aggressive non-Hodgkin's lymphoma. The International Non-Hodgkin's Lymphoma Prognostic Factors Project. N Engl J Med 329 : 987-994, 1993.

11) Coiffier B, et al:CHOP chemotherapy plus rituximab com- pared with CHOP alone in elderly patients with diffuse large-B-cell lymphoma. N Engl J Med 346 : 235-242, 2002.

12) McLaughlin $P$, et al: Rituximab chimeric anti-CD20 monoclonal antibody therapy for relapsed indolent lymphoma : half of patients respond to a four-dose treatment program. J Clin Oncol 16 : 2825-2833, 1998.

13) Magrath I, et al: Adults and children with small noncleaved-cell lymphoma have a similar excellent outcome when treated with the same chemotherapy regimen. J Clin Oncol 14 : 925-934, 1996.

14) Shimoyama $M:$ Diagnostic criteria and classification of clinical subtypes of adult T-cell leukaemia-lymphoma. A report from the Lymphoma Study Group (1984-87). Br J Haematol 79 : 428-437, 1991.

15) Yamada $Y$, et al : A new G-CSF-supported combination chemotherapy, LSG15, for adult T-cell leukaemialymphoma : Japan Clinical Oncology Group Study 9303. Br J Haematol 113 : 375-382, 2001.

16) Tsukasaki K, et al : VCAP-AMP-VECP compared with biweekly CHOP for adult T-cell leukemia-lymphoma : Japan Clinical Oncology Group Study JCOG9801. J Clin Oncol 25 : 5458-5464, 2007.

17) Philip T, et al : Autologous bone marrow transplantation as compared with salvage chemotherapy in relapses of chemotherapy-sensitive non-Hodgkin's lymphoma. N Engl J Med 333 : 1540-1545, 1995. 